\title{
Surficial glaciology of Jakobshavns Isbræ, West Greenland: Part II. Ablation, accumulation and temperature
}

\author{
K. Echelmeyer, W. D. Harrison, T. S. Clarke and C. Benson \\ Geophysical Institute, University of Alaska-Fairbanks, Fairbanks, Alaska 99775-0800, U.S.A.
}

\begin{abstract}
Accumulation studies along the lowermost $100 \mathrm{~km}$ of Jakobshavns Isbræ show that the local net balance above the equilibrium line $(1210 \mathrm{~m}$ elevation in 1986) is significantly less than that measured along the EGIG line about $100 \mathrm{~km}$ further north. This indicates the presence of a precipitation low in this region which will affect any global mass-balance assessment for the Jakobshavns Isbræ drainage basin. Comparison of the estimated calving and ablation fluxes shows that calving removes about twice as much mass from this drainage basin as does melting. Basal melting over the entire basin accounts for about $20 \%$ of the total ice loss by ablation. Temperature measurements at $12 \mathrm{~m}$ depth along the same section of the isbræ show the warming effects of refreezing meltwater and cooling effects of severe crevassing. In addition, there is a significant variation in temperature across the fast-moving ice stream which is probably caused by deformation heating in the shear margins which delineate the ice stream within the ice sheet. This lateral temperature gradient could be important in ice-stream dynamics through its effects on ice rheology. Detailed measurements within the percolation facies show that surface melt can penetrate up to $3 \mathrm{~m}$ by piping in cold firn, and, upon refreezing, can cause significant warming at these depths.
\end{abstract}

\section{INTRODUCTION}

Jakobshavns Isbræ is a large, fast-moving glacier/ice stream which drains approximately $6.5 \%$ of the total area of the Greenland ice sheet. It flows from an area of dry, cold snow at high elevations, down through the entire recognized sequence of glacier facies to an extensive ablation area and on to its calving front. As such, it provides an ideal system in which to investigate several interesting glaciological problems, some of which are of global concern: what is the current state of health of the ice sheet? What are the effects of the refreezing of meltwater on the temperature regime of an ice sheet? How will this refreezing buffer the response of an ice sheet (and, ultimately, sea level) to a warming climate? The first of these questions has been addressed in relation to Greenland by several authors, from Bader (1961) and Benson (1962) to Meier and others (1985) and Zwally (1989), to name a few. No clear consensus has been reached, mainly because of the paucity of local mass-balance data around the ice sheet. The second question has also been discussed by several authors, including Müller (1976), Hooke (1976) and Hooke and others (1983). These authors showed that latent-heat release upon refreezing at and just above the equilibrium line is a major source of warming in snow and firn, and that ice/firn temperatures in this region generally do not represent the mean annual air temperature at the surface. The third question has recently been brought into discussion by Meier and others (1985) and Pfeffer and others (1990). Unless impermeable ice layers are formed near the surface, surface meltwater will be transported into the cold firn where it refreezes and does not become available for run-off. Only when the entire firn pack down to some impermeable horizon becomes saturated and warmed to $0^{\circ} \mathrm{C}$ will surface melt in the wet snow and percolation facies be free to affect sea level. Until then it is, for the most part, stored in the firn.

In this paper, the second in a three-part series on the near-surface glaciology of Jakobshavns Isbræ, we describe the local mass-balance and temperature regime of the lower part of the glacier up to the wet snow/lower percolation facies. Discussion in terms of the questions posed above is given for each particular set of observations: local mass balance, near-surface ice/firn temperatures and a detailed study of temperature at a location where downward infiltration and refreezing of meltwater occur.

Local mass-balance and near-surface temperature measurements in ice/firn were made at several locations along the central flowline of the lower part of Jakobshavns Isbræ, from the floating terminus up to an elev- 


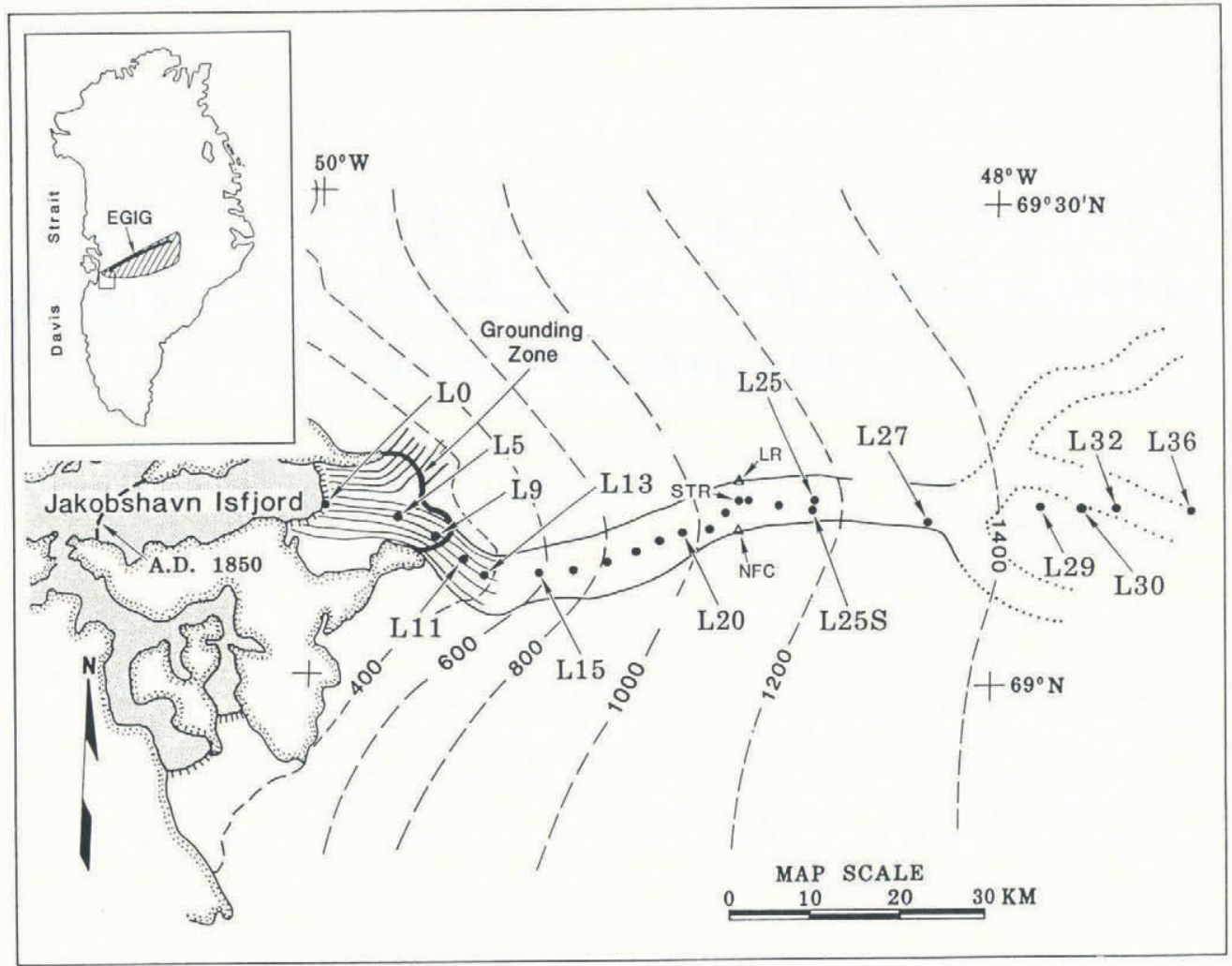

Fig. 1. Map of Jakobshavns Isbra showing the location of markers described in the text. Approximate elevation contours are from H. Brecher and T. Hughes (personal communication). The insert shows approximate drainage basin (from Bindschadler and others, 1989) and the EGIG line.

ation of about $1600 \mathrm{~m}$. Markers at these locations are designated L1 to L36; their positions are shown in Figure 1. Longitudinal distance inland is measured along the curving flowline with origin fixed at the center of the grounding zone. The position and elevation of these markers and the coordinate system have been described in detail in the first paper of this series, designated Part I (Echelmeyer and others, 1991). The third paper (paper in preparation by K. A. Echelmeyer) is designated Part III.

\section{ACCUMULATION, ABLATION AND GLACIER FACIES}

The climate of the lower part of Jakobshavns Isbræ is given a maritime component by its proximity to the seasonally open water of Disko Bay and Davis Strait. Incident storm tracks come primarily from the southwest and are often partially blocked by the intervening Sukkertoppen Ice Cap and topographic high. Much of a storm's moisture content could be dropped on this orographic barrier (Bender, 1984). Thus, the drainage basin of Jakobshavns Isbræ may lie in somewhat of a more "continental" precipitation shadow relative to the ice sheet to the north in the vicinity of the EGIG traverse and to the south near the Dye sites. This possibility has been further discussed by Bender (1984), who described the general storm tracks and proposed a precipitation map for Greenland. Bender noted that there is a paucity of data in the region of this Sukkertoppen Ice Cap shadow, and therefore its existence has not been well defined.
From the $60 \mathrm{~km}$ wide ablation area, Jakobshavns Isbræ drainage basin ascends across the equilibrium line into the region of superimposed ice, and then across the wet snow, percolation and dry snow facies, as defined by Benson 1962) and further amended by Williams and others (1991). The first two, and the lower part of the percolation facies, will be discussed here. The dry snow facies occurs several hundred kilometers inland from the coast to an elevation of about $2500 \mathrm{~m}$ (Benson, 1962), and thus, it is well removed from the region shown in Figure 1.

Ablation and accumulation data were obtained in all but the dry snow and upper percolation facies, primarily by measuring stake heights. A few snow pits were made and shallow ice cores were taken in the accumulation area during 1985. Density measurements made within the snow pits are used to reduce accumulation data at the stakes to water equivalent wherever possible. An ice density of $900 \mathrm{~kg} \mathrm{~m}^{-3}$ was used in the ablation area.

Balance measurements span 2 years (1984-86) at most locations, with a few data sets extending to 1989 . The net mass balance over one balance year (in water equivalent) is denoted $\dot{b}\left(\mathrm{ma}^{-1}\right)$. Although the beginning of the balance year varies with elevation, it is taken to be 1 June. We have taken the balance year to be from the end of the accumulation season to the end of the next accumulation season, as opposed to that defined by the end of the melt season, because this most closely overlaps the dates of our field programs. However, the actual period of measurement for some of the data presented does not 
coincide well with this "balance year" and some adjustment was necessary.

\section{Ablation}

Periodic stake measurements within the ablation area give a resonably accurate estimate of the rate of ablation and overall net balance because there is no internal accumulation nor settling of the markers (which had cork inserts to prevent melting of the pole into the ice). Except at the lowest elevation, $\sim 100 \mathrm{~m}$, the error in balance in the ablation area is about $\pm 0.1 \mathrm{~m} \mathrm{a}^{-1}$. This error is due to the necessity of extrapolating to the balance year and to the rough surface topography in much of this zone. The error at $100 \mathrm{~m}$ a.m.s.l., $\pm 0.3 \mathrm{~m} \mathrm{a}^{-1}$, is somewhat greater than elsewhere due to the large extrapolation required from only 1 year's summer measurements.

Net mass balance as a function of elevation is shown in Figure 2. Strong ablation occurs at lower elevations. The ablation gradient, $\mathrm{d} \dot{b} / \mathrm{d} z$, was about $3.8 \mathrm{~m} \mathrm{a}^{-1} \mathrm{~km}^{-1}$ (or $380 \mathrm{~g} \mathrm{~cm}^{-2} \mathrm{a}^{-1} \mathrm{~km}^{-1}$ ) within the ablation area up to an elevation of about $1210 \mathrm{~m}$, excluding the value at $100 \mathrm{~m}$ a.m.s.l. Similar gradients were obtained by Bauer (as cited by Ambach (1977)) in 1958-59 along the EGIG line, approximately $60 \mathrm{~km}$ north of our central flowline $\left(\mathrm{d} \dot{b} / \mathrm{d} z \approx 3.4 \mathrm{~m} \mathrm{a}^{-1} \mathrm{~km}^{-1}\right)$ and by Thomsen (1984) during 1982-83, also near the EGIG line $(\mathrm{d} \dot{b} / \mathrm{d} z \approx$ $\left.3.5 \mathrm{~m} \mathrm{a}^{-1} \mathrm{~km}^{-1}\right)$. Ablation rates during July and early August from 1984 to 1988 were given by Echelmeyer and Harrison (1990, fig. 5), with peak daily rates of about $44 \mathrm{~mm} \mathrm{~d}^{-1}$ w.e. at low elevations and about $15 \mathrm{~mm} \mathrm{~d}^{-1}$ w.e. at $1000 \mathrm{~m}$. These daily rates agree well with those determined by Ambach (1977), but are up to twice those measured by Thomsen in 1982-83. As Thomsen (1984) noted, the summer of 1983 was abnormally cool and stormy, with a mean temperature of $5.4^{\circ} \mathrm{C}$ at the coastal station in Jakobshavn, compared with $7.0^{\circ} \mathrm{C}$ in 1959 , for

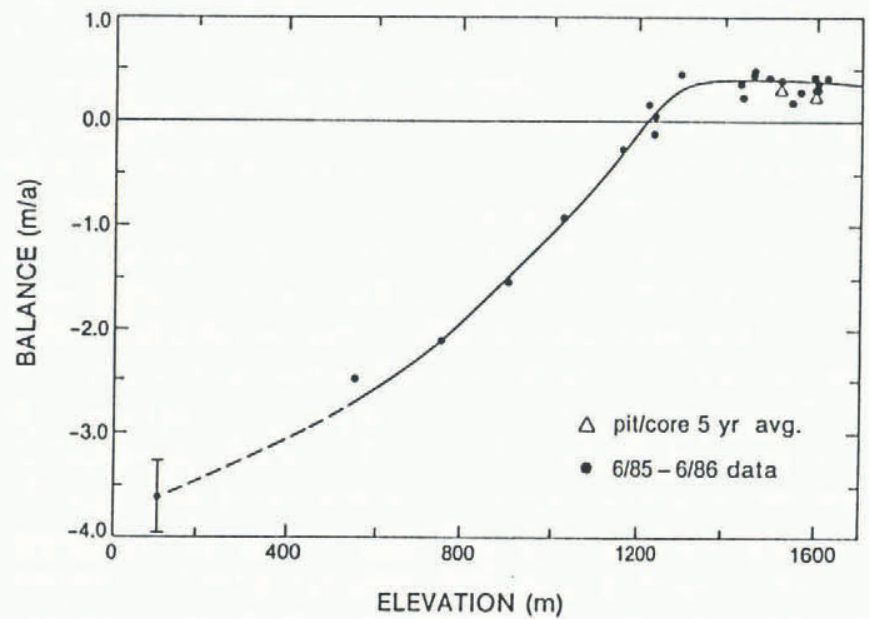

Fig. 2. Local annual mass balance in meters (water equivalent) per year. Measurements were made along the central flowline up to the equilibrium line, and along various transverse profiles through this central flowline above the equilibrium line. Triangles represent the upper 5 year average from the snow pits and cores made in 1985 at L30 (left) and L36 (right). Errors are discussed in the text. Solid line indicates a best fit to the observations. example. Thus, much lower ablation rates would have been expected during that summer.

Ambach (1963) and Braithwaite and Olesen (1990) found that the predominant energy source for melting in western Greenland is short-wave radiation. This energy flux is proportional to $(1-\alpha)$ where $\alpha$ is the effective albedo of the ice surface. The melting rate on lower Jakobshavns Isbræ may be somewhat larger than elsewhere because of the relatively large amount of wind-blown dust which is present during the summer months in this region. This dust comes from the recently deglaciated, barren terrain surrounding this glacier and is more pronounced than along the coastal region to the north. In addition, the snowpack in the Jakobshavns Isbræ region is thinner because it lies in an area of reduced accumulation, and this would increase the overall melt in the ablation area. These factors could also affect the ablation gradient.

The period of surface melting on the lower part of the glacier is approximately early June through late August, with a decreasing duration and later onset at higher elevations. During the early part of this season the thin $(<1 \mathrm{~m})$, patchy snow cover in the ablation area is melted. An estimate for the entire melt season of the input of surface meltwater to the hydrologic system from Jakobshavns Isbræ drainage basin may be obtained by integrating the melt over the ablation area, including the melting of winter snow, using the width of the basin and ablation rates from Echelmeyer and Harrison (1990). This ablation flux is $8-15 \mathrm{~km}^{3}$ water per year, the uncertainty being dominated by the undetermined increase in surface area due to intense crevassing. A small amount of run-off comes from the region of superimposed ice and wet snow above the equilibrium line. This was partially accounted for by continuing the integration of ablation up to an elevation of about $1300 \mathrm{~m}$ (where the ELA is $1210 \mathrm{~m}$ ), which adds about $0.5 \mathrm{~km}^{3} \mathrm{a}^{-1}$ to the total. The actual line of no run-off is somewhat higher, but the contribution of this additional run-off is negligible, especially when the uncertainty arising from the increase in surface area due to crevassing is considered. The total ablation flux is approximately $4-7 \%$ of the total surface meltwater flux of the Greenland ice sheet as estimated by, for example, Benson (1962, p. 89) and Reeh (1985).

An additional input of meltwater comes from basal melting along the ice stream. Calculations (e.g. Radok and others, 1982; paper in preparation by K. A. Echelmeyer, M. Funk and A. Iken) suggest that the basal ice reaches the melting point about $250-300 \mathrm{~km}$ inland, and that there is a layer of temperate ice of finite thickness at the bed from $150 \mathrm{~km}$ inland to the coast. Meltwater is generated by deformational heating along this part of the flowline. Echelmeyer and Harrison (1990) calculated an input of about $2-3 \mathrm{~km}^{3} \mathrm{a}^{-1}$ from this source, distributed throughout the year. There will also be some basal melting along the floating ice tongue. These calculations show that, while surface melting is the dominant source of fresh water from the basin, basal melting may be as much as $20 \%$ of the total surface melt. This is large in comparison to most other temperate and sub-polar glaciers. Indeed, basal melting in the region where the bed is at the melting point (which is much larger than the surface ablation area) amounts to an av- 
erage surface lowering of $0.06-0.08 \mathrm{~m} \mathrm{a}^{-1}$ over this entire region. This is significant considering the relatively small positive surface balance above the equilibrium line.

Nearly all of the meltwater generated from both surface and basal melting enters the fiord near its head. It can often be seen as an upwelling plume at the calving front (Echelmeyer and Harrison, 1990). The ensuing downfiord fresh-water current helps force iceberg drift along the ice-packed fiord. Additional downfiord motion of the icebergs comes from push by the moving glacier in the fiord and by wind. The salinity of water in the fiord near the calving front is a strong function of this freshwater input. As such, it affects the surface elevation of the floating terminus through buoyancy (Part I).

Much of the meltwater generated at the surface flows into the supraglacial lakes. Some of the lakes do not drain continuously; rather they appear to fill to a given level and then drain at a rapid rate through an unknown drainage system (personal communication from T. Hughes and H. Brecher). The effect of such supraglacial storage and delayed drainage on mass balance needs to be further investigated.

\section{Equilibrium line}

The equilibrium line was located at an average elevation of $1210 \mathrm{~m}$ between 1984 and 1986 . Its precise position is difficult to determine, however, because large amounts of superimposed ice are formed near this line, and it is often difficult to decide whether or not all of this superimposed ice is melted by the end of the ablation season at a given elevation. During the summer, work on the glacier surface near the equilibrium line is made difficult by the presence of extensive, often deep, slush swamps waiting to trap the unwary skier or snowmachiner. By the later part of the melt season, these swamps extend inland across the superimposed ice facies and into the lower wet snow facies. The superimposed ice zone extends from about 1210 to $1350 \mathrm{~m}$ while the wet snow facies occurs from 1350 to about $1500 \mathrm{~m}$. The distinction between different glacier facies depends, in part, on whether or not the entire snowpack reaches the melting point. For this reason, the elevation bands for the different facies stated here are somewhat subjective since only limited temperature data are available from our measurements in the lower part of the drainage basin, and because localized meltwater piping can raise the firn temperature to $0^{\circ} \mathrm{C}$ in the neighborhood of a "pipe" near a temperature sensor, while not influencing the bulk firn temperature (as described in section 4).

Equilibrium-line altitudes (ELA) near the EGIG line have been given by several authors. Heuberger (1954) reported an ELA of nearly 1500 m, while Ambach (1977) and Bauer and others (1968) gave $1250 \mathrm{~m}$ for 1959 and Thomsen (1984) gave $1030 \mathrm{~m}$ for 1983 . The latitudinal variation in ELA is likely to be small between our flowline and the EGIG line, and thus we may compare our result directly with these values. Our 1985-88 value of $1210 \mathrm{~m}$ is close to that of Ambach and Bauer and others, and considerably higher than that of Thomsen, whose result was for a cool year. Braithwaite and Thomsen (1983) have modeled the mass balance in western Greenland. Their model suggests that the mean ELA over the past 20 years in this region is around $1300 \mathrm{~m}$, which is reasonably close to the observed values, except that quoted by Heuberger (1954).

Realizing that errors involved in locating the equilibrium line can be large in areas where superimposed ice is formed and where temporal coverage of balance throughout the year is limited, it is interesting to note the large inter-annual variation in ELA shown by the above values. Changes in short-term meteorological conditions must give rise to these variations, and one must be extremely cautious when interpreting ELA fluctuations as an indicator of climate change in such a region.

\section{Accumulation}

Accumulation above the equilibrium line was determined by stake and snow-pit measurements. The determination of accumulation from stake-height measurements is subject to stake movement in the firn and to densification errors, especially in the wet snow and percolation facies. Therefore, the accumulation derived from these stake measurements is a minimum estimate. A related source of error is the possibility of internal accumulation in the form of ice lenses and glands at depth. We have used information from the shallow pits and cores to correct for this sub-surface accumulation wherever possible. This is a chronic problem in most studies done in and above the wet snow facies. As a result of the different errors, the individual results presented here are believed to have an accuracy of $\pm 0.01 \mathrm{~m} \mathrm{a}^{-1}$ locally.

Above the equilibrium line, over an elevation range of $400 \mathrm{~m}$, the balance is relatively constant with a mean value of about $0.35 \mathrm{~m} \mathrm{a}^{-1}$, corresponding to about $0.77 \mathrm{~m} \mathrm{a}^{-1}$ firn of density $450 \mathrm{~kg} \mathrm{~m}^{-3}$ (Fig. 2). This feature of the accumulation data is in direct contrast to the rapid change of local balance within the ablation area.

The large number of data points in the accumulation area within a relatively small elevation band stems from stake data collected along north-south traverses made at L30 and L25. The data show significant scatter about the smooth curve which is caused by spatial inhomogeneity in snow cover. The scatter is on the order of $\pm 0.15 \mathrm{~m} \mathrm{a}^{-1}$, which is greater than the error in an individual measurement (described above). A similar variation has been found by others working in Greenland (e.g. personal communication from I. Whillans), and it is significant in that measurements made at a single location, be it at a stake, in a pit or along a shallow core, do not necessarily give a true estimate of the mean accumulation rate.

Preliminary analysis of snow-pit $(3 \mathrm{~m})$ and ice-core (up to $14 \mathrm{~m}$ ) stratigraphy from July 1985 suggests that the mean annual balance over the previous 5 years is roughly $0.30 \mathrm{~m} \mathrm{a}^{-1}$ at L30 (1520 ma.m.s.l. and even lower, $\sim 0.24 \mathrm{~m} \mathrm{a}^{-1}$, at L36 (1595 ma.m.s.l.), as shown by the triangles in Figure 2. The balance as measured by stake heights from 1985 to 1986 agrees fairly well with these mean values, as does the slight decrease with altitude indicated at our uppermost sites.

Along the EGIG line, Benson (1962) found that the balance reached a maximum at about $2000 \mathrm{~m}$. In the early $1950 \mathrm{~s}$, this maximum was about $0.57-0.60 \mathrm{~m} \mathrm{a}^{-1}$, while at an elevation of $1700 \mathrm{~m}$ the balance was about $0.5 \mathrm{~m} \mathrm{a}^{-1}$. Unfortunately, Benson's data do not extend to elevations less than $1746 \mathrm{~m}$, while out data extend only up to $1600 \mathrm{~m}$. Thus, there is no overlap for direct 
comparison. However, if the data from Benson (1962) are extrapolated down to $1600 \mathrm{~m}$, a net balance of $0.50 \mathrm{~m} \mathrm{a}^{-1}$ is obtained. This is $40 \%$ greater than the mean value of $0.35 \mathrm{~m} \mathrm{a}^{-1}$ measured at this elevation in our study region. Unfortunately, we have no data to confirm extrapolation up to $2000 \mathrm{~m}$, but our results do seem to indicate that there may be a precipitation low which encompasses much of Jakobshavns Ibræ drainage basin and the ice sheet to the south, as originally proposed by Bender (1984). Accumulation rates could be up to $40 \%$ lower than those obtained along the EGIG line, which follows the north margin of Jakobshavns Isbræ drainage basin.

An interesting feature of the snowpack during mid to late summer in the elevation range from about 1300 to $1600 \mathrm{~m}$, and possibly higher, is the presence of an extensive, nearly continuous ice layer at about $0.2-0.4 \mathrm{~m}$ depth. This ice layer is a few centimeters thick and often prevents stake emplacement without drilling. In pits at L29, L30 and L36, the ice layer was found at a depth of $0.33,0.30$ and $0.49 \mathrm{~m}$, respectively, during July 1985 . The ice layer was $2-5 \mathrm{~cm}$ thick at these locations. Numerous other ice layers were found at depths below this, with some layers occurring between annual surfaces. Cores were predominantly ice at a depth of about 5, 9 and $10 \mathrm{~m}$ at L29, L30 and L36, respectively. The uppermost ice layer is probably an indication of the infiltration horizon for surface melt. Its formation is further discussed in section 4 and it may be related to the maximum depth of infiltration noted by Pfeffer and others $(1990$, p. 238$)$ in the Canadian Arctic.

\section{Balance assessment of Jakobshavns \\ Isbræ drainage basin}

The mass-balance data obtained along the central flowline of lower Jakobshavns Isbræ shows increased ablation and decreased accumulation in comparison to that found along the EGIG line to the north. Calculations of the mass flux for this basin will be strongly affected by this reduction in balance, especially if it does exist inland. Previous balance assessments for Jakobshavns Isbræ drainage basin, such as those by Bindschadler (1984) and Pelto and others (1989), used accumulation data from Benson (1962) along the EGIG line. Furthermore, Bindschadler (1984) did not take the negative balance in the ablation area into account. These balanceflux calculations were then compared to the calving flux estimated on the basis of an ice thickness at the calving front which was too large by $6-45 \%$ (Part I). These comparisons indicated that the basin was in rough equilibrium, with influx equaling outflow. However, the data presented in this section indicate that the actual accumulation at some locations in this basin may be up to $30-40 \%$ lower than used in these earlier studies.

If our data are combined with the accumulation map of Bender (1984) and, if the newly revised drainage-basin map of Bindschadler and others (1989) is used, a balance flux at the terminus of $30.1 \mathrm{~km}^{3} \mathrm{a}^{-1}$ is obtained. If, on the other hand, the balance data along the EGIG line are used with the new basin dimensions, the balance flux at the terminus is $37.2 \mathrm{~km}^{3} \mathrm{a}^{-1}$, a $24 \%$ difference.

For comparison, revised estimates of the calving flux, based on improved estimates of the terminal ice thickness (Part I) and velocity field (Part III), and including the flux of basal melt, are about $25-28 \mathrm{~km}^{3} \mathrm{a}^{-1}$. Thus, if a precipitation low encompasses the drainage basin, as suggested by the balance data presented here and by Bender (1984), Jakobshavns Isbræ drainage basin is about in balance within the errors of the flux estimates. However, if the accumulation and ablation were to be determined from the EGIG line data, a thickening of about $0.09 \mathrm{~m} \mathrm{a}^{-1}$ over the entire $1.1 \times 10^{5} \mathrm{~km}^{2}$ basin is suggested. This would be significant, as it is of the same magnitude as the value of $0.2-0.3 \mathrm{~m} \mathrm{a}^{-1}$ predicted by Zwally (1989) and Zwally and others (1989) for the Greenland ice sheet based on satellite altimetry.

While the above discussion is only approximate in nature, it points to the consequences of the reduced local mass balance found in this study, and the need for further accumulation measurements in the interior of this drainage basin.

\section{SURFACE ICE TEMPERATURE}

Ice temperature near the surface along the glacier center line was measured using thermistors and/or thermocouples installed at various depths down to $14 \mathrm{~m}$ in steamdrilled holes. The accuracy of the thermocouple measurements is $\pm 0.3 \mathrm{~K}$, whereas the few thermistor records are about an order of magnitude better. Unfortunately, the idiosyncrasies of the steam drill did not allow all holes to be drilled to the ideal depth of $14 \mathrm{~m}$ where, according to Hooke (1976) and Hooke and others (1987), the mean temperature in ice most closely approximates the mean annual air temperature at the surface. Most holes did reach a depth of $12 \mathrm{~m}$, however, and thus we report the temperature at this depth, in some cases interpolated as the mean near-surface ice temeprature, $T_{\mathrm{s}}$.

Observations showed that at this depth, and even at $14 \mathrm{~m}$, there was significant seasonal variation. Furthermore, there is considerable structure in the temperature profiles. The mean value at $12 \mathrm{~m}$ was about $0.2 \mathrm{~K}$ higher than that at $14 \mathrm{~m}$. Seasonal temperature variation at $12 \mathrm{~m}$ depth was on the order of $0.6 \mathrm{~K}$ about the mean, while at $14 \mathrm{~m}$ it was somewhat less, as measured at a few locations. At most sites, however, only one measurement was made (well after any installation transient had decayed (i.e. 1 month to 1 year)) and, thus, the mean annual $T_{\mathrm{s}}$ could only be estimated. Because the temperature was measured at least once during the summer period between 15 July and 30 August at almost all sites, we report this value as $T_{\mathrm{s}}$ in the following analysis.

As examples of the variation in temperature with depth and time, results at L23 and L20, two points below the equilibrium line at elevations of 1030 and $910 \mathrm{~m}$, respectively, are shown in Figures 3 and 4 . The behavior at different depths is complex, with the propagation of the winter "cold wave" into the ice, the decay in amplitude of the seasonal fluctuation with depth, and warming in the snowpack by latent-heat release. In addition, a snow layer of variable thickness of up to $10 \mathrm{~m}$ occurs during the winter and spring. This snow layer was not taken into account when computing the depth to each sensor. Thus, the "surface" temperature ("0" $\mathrm{m}$ ) will be strongly influenced by the snow layer, acting as both an insulator in winter, and as a reservoir of refreezing meltwater in the spring. 


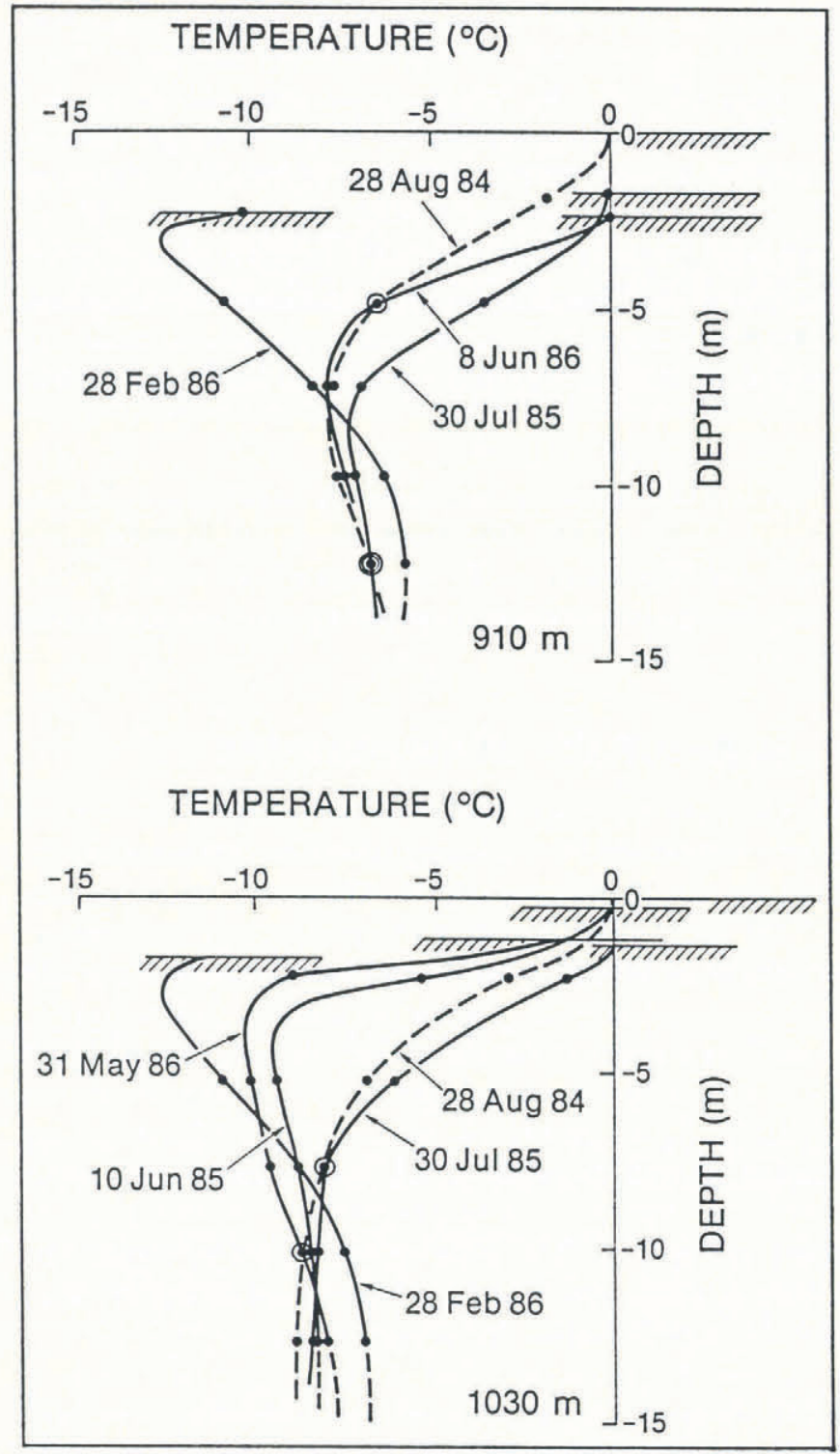

Fig. 3. Variation of temperature with depth below the ice surface at different times of the year as measured at L20 (910 ma.m.s.l.) and L23 $(1030 \mathrm{~m})$. The ice surface is melting, so its elevation changes from curve to curve.

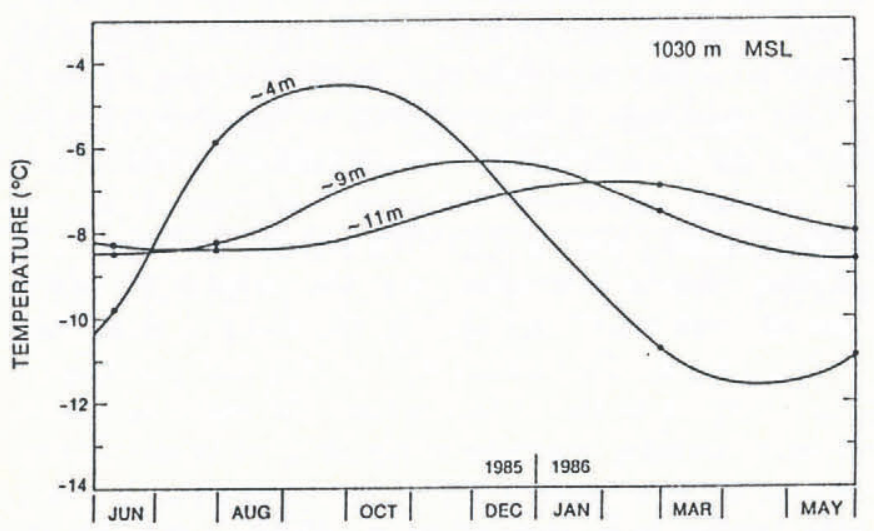

Fig. 4. Seasonal variation of temperature at L23 as measured at various depths below the ice surface. Curves are sinusoidal approximations through the data.
At both locations the amplitude of the temperature variation is $\sim 1.4 \mathrm{~K}$ at $10 \mathrm{~m}$, and $1.2 \mathrm{~K}$ at $12 \mathrm{~m}$. The $12 \mathrm{~m}$ temperature is near its annual minimum in late summer, thus being completely out of phase with the surface, and it is about $0.6 \mathrm{~K}$ less than the mean annual temperature at this depth. There are insufficient data to determine this correction at other locations, but it is likely to be similar below the equilibrium line. In contrast, in the dry snow facies the phase reversal occurs at a depth of about $7 \mathrm{~m}$ (Benson, 1962). At and above elevations where superimposed ice forms, this correction term is likely to differ because of latent-heat input (Hooke and others, 1983). Therefore, we state only $T_{\mathrm{s}}$ in what follows, recognizing that the mean annual temperature at $12 \mathrm{~m}$ (and at $14 \mathrm{~m}$ ) is likely to be up to $0.6 \mathrm{~K}$ higher than that tabulated, depending on location and the time of measurement. It should also be noted that at all elevations (except near $\sim 100 \mathrm{~m}$ ) the $10 \mathrm{~m}$ temperature at this time of year was $0.2-1.0 \mathrm{~K}$ lower than that at $12 \mathrm{~m}$, with the greatest difference occurring near the equilibrium line. We thus find that from the superimposed ice zone down through the ablation area there is a significant variation in temperature at $10-12 \mathrm{~m}$ depth, and that it is difficult to interpret the ice temperature at these depths in terms of a mean annual "surface" temperature. The boundary layer for seasonal variation varies in thickness inversely with the ablation rate throughout the ablation area, as is shown in the Appendix, and this will also affect the interpretation of our results (as well as any data from the ablation areas of other sub-polar glaciers).

The variation of $T_{\mathrm{s}}$ with elevation along the glacier center line from the floating terminal lobe upward to L36 is shown in Figure 5. Also shown in this figure are the approximate boundaries of the various snow/ice facies. The temperature decreases at a rate of about $-7 \mathrm{~K} \mathrm{~km}^{-1}$ with increased elevation, as shown by the line of best fit in this figure.

This gradient may be compared with that obtained

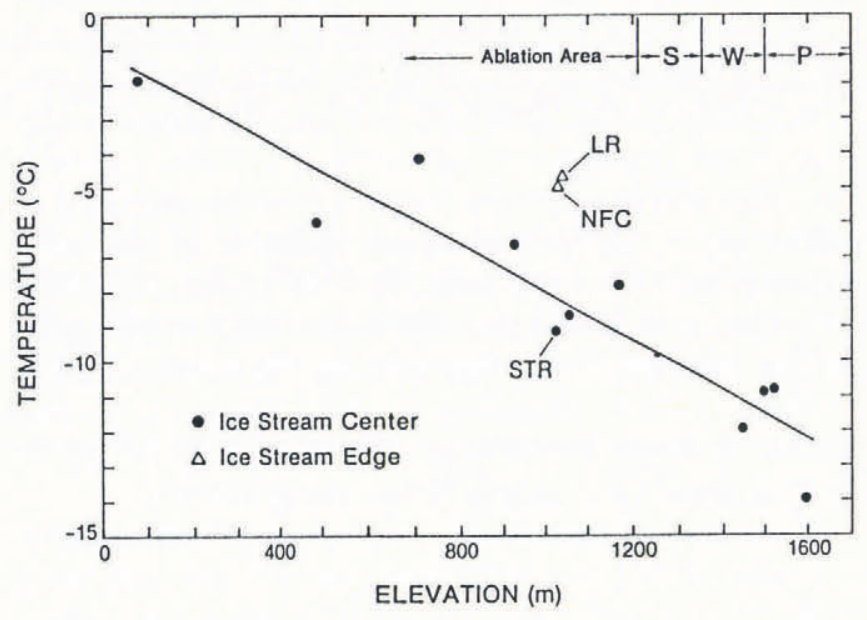

Fig. 5. Temperature at $12 \mathrm{~m}$ depth along the ice stream as measured in late summer. The locations of the three labeled points are shown in Figure 1. Line of best fit is also shown. Facies boundaries are shown along upper boundary, where $S$ is superimposed ice, W is wet snow and $P$ is percolation facies. 


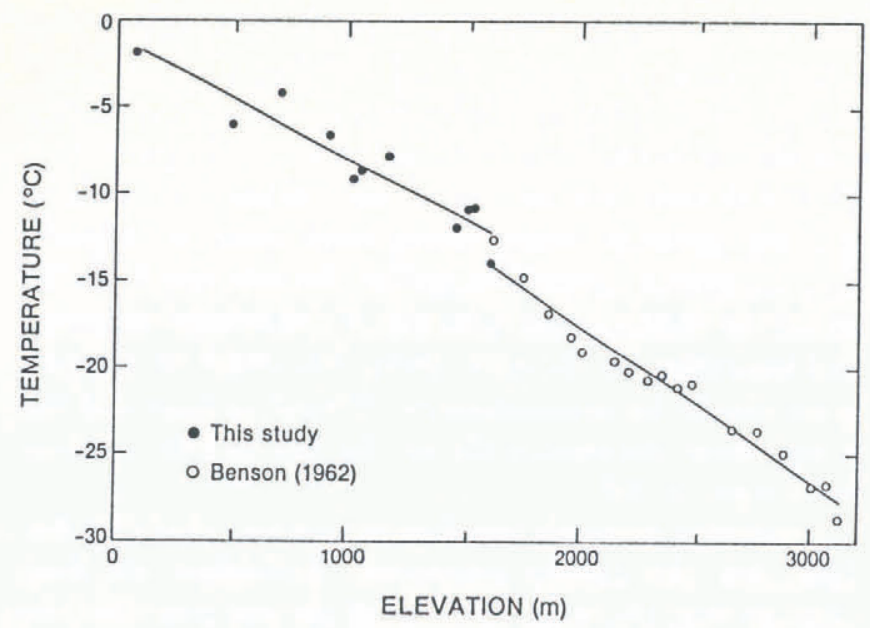

Fig. 6. Temperature vs elevation from this study (at 12m depth) and from Benson (1962; at $10 \mathrm{~m}$ ). Lines of best fit through respective data sets are shown.

by Benson (1962, fig. 37) along a traverse approximately $100 \mathrm{~km}$ to the north (the EGIG line at $\sim 70.4^{\circ} \mathrm{N}$ ). Benson found that $\mathrm{d} T_{\mathrm{s}} / \mathrm{d} z=-9 \mathrm{~K} \mathrm{~km}^{-1}$ for elevations from 1600 to $3200 \mathrm{~m}$ when measured at $10 \mathrm{~m}$ in firn. Such measurements should be comparable to our $12 \mathrm{~m}$ values when the differing thermal properties of firn and ice are taken into account (Hooke, 1976). Some of Benson's (1962) data have been adjusted for latitudinal differences (1.1 K deg lat.), and are replotted along with the present results in Figure 6.

The climatological lapse rate in mean annual air temperature for western Greenland has been calculated by Ohmura (1987) who found that $\mathrm{d} T / \mathrm{d} z=$ $-8.3 \mathrm{~K} \mathrm{~km}^{-1}$. This lapse rate is determined solely from atmospheric measurements near the surface, and it is nearly equal to the dry adiabatic lapse rate, indicating that katabatic winds are important in mixing the atmosphere near the surface. It is interesting that the altitudinal gradient along the lower part of the glacier is smaller than this, while that of Benson (1962), measured at high elevations, is somewhat greater. This is true even though Benson's results from the dry snow and upper percolation facies should be more representative of the mean annual air temperature than ours which were taken in zones where surface melting and refreezing of meltwater occur.

An explanation for the difference in our altitudinal gradient and that of Benson (1962) lies in the fact that our traverse spans several facies from the lower part of the percolation facies, across the superimposed ice zone and into the ablation area. In this case, the effects of latent-heat warming are greatest along the upper reaches of our profile, while the effects of intense, non-water-filled crevassing, allowing the "cold wave" to propagate to a greater depth in crevasse blocks, are greatest at lower elevations. Other factors affecting the gradient along our profile include the constraint that the ice temperature is limited above by its melting point, whereas the air temperature may be significantly warmer in summer, and the idea that ablation removes a part of the cold layer formed in winter (Appendix). For these reasons, we might expect our altitudinal gradient to be somewhat less steep than would otherwise be the case. On the other hand, Benson's (1962) traverse goes from the dry snow facies into the upper percolation facies where some latent heat is released. Thus, the temperatures at lower elevations along that profile would be raised somewhat, increasing $\mathrm{d} T_{\mathrm{s}} / \mathrm{d} z$. Benson's lowermost data points show signs of this warming at his lower elevations.

The data in Figure 5 scatter about a simple linear trend with elevation; there is significantly more scatter than in Benson's (1962) data from higher elevations. The variation in temperature from a linear trend may be explainable by the factors mentioned above, as well as the fact that some stakes were located off the ice-stream center line in zones of high shear strain. The heating due to refreezing amounts to about $2 \mathrm{~K}$ (the deviation from the linear trend at about $1200 \mathrm{~m}$ ), which is less than expected from other studies (e.g. Paterson, 1981, p. 191; Hooke and others, 1983).

\section{Temperature across the ice stream}

Temperatures from two locations, shown as triangles in Figure 5, merit special comment. These locations were on the north and south margins of the ice stream near L23 and STR. The temperatures are about $4.5 \mathrm{~K}$ higher than the center-line temperature (at STR) measured at roughly the same time. All three locations are in the ablation area, with similar winter snowpacks, so the heating from refreezing melt and insulation should be comparable at each site. The marginal sites are a few meters higher in elevation but which should not affect the temperature significantly. Crevassing is stronger at the marginal sites.

There are two possible explanations for these highly elevated marginal temperatures. First, the latent heat released by refreezing of meltwater trapped in the numerous crevasses may lead to higher temperatures. Secondly, there is very strong lateral shear between the ice stream and the surrounding ice sheet at these locations $\left(\dot{\epsilon}_{x y} \sim 0.3\right.$ year $^{-1}$; see Part III). The deformational heating under a large transverse velocity gradient could cause substantially higher temperatures at the margins. The latter explanation is favored because many of the crevasses, especially to the north, are not filled with water and because other center-line sites where waterfilled crevasses are sometimes found (L18, L16) do not show similar warming. Furthermore, Iken and others (in press), found that borehole temperature profiles at depth also vary strongly across the ice stream, with temperatures through the upper half of an ice column at both margins being elevated by several Kelvin relative to those in the upper half of a column located at the center of the ice stream.

The calculation of the temperature difference at shallow depths between the center of an ice stream and the margins, where high shear strain rates and a large shear stress (approximately $150 \mathrm{kPa}$ at this location on Jakobshavns Isbræ) combine to produce substantial viscous heating, is a complex problem. Several factors must be taken into account, including: (1) the influx of ice from outside the ice stream through the shear margins; (2) the thermal boundary layer imposed by the air temperature at the ice surface; (3) vertical advection, which either 
accentuates this boundary layer in an accumulation area or decreases its thickness in the ablation area; (4) the distribution of viscous heating at depth; and (5) the nonlinear flow properties of ice. Analyses of the influence of these factois on the temperature distribution across an ice stream is in progress (paper in preparation by K. A. Echelmeyer and W.D. Harrison). These authors show that, in most cases, conduction plays a limited role in determining the cross-stream temperature distribution, and that, under favorable conditions, the margins of an ice stream can be substantially $(\sim 5-10 \mathrm{~K})$ warmer than the center, even at depths of $10-15 \mathrm{~m}$. Based on this work, it is plausible that the temperature difference observed across Jakobshavns Isbræ can be attributed, at least in part, to viscous heating in the marginal shear zones. The strong influx of ice across the margins can be shown to be the most important factor determining the magnitude of the transverse temperature difference at this location.

The warmer ice temperatures at the margins means that this ice will have a markedly reduced effective viscosity compared to that on the center line (roughly three times less at the margins than the center), even if the effective stress levels were the same. This could lead to a positive feed-back mechanism for ice-stream formation, which acts in addition to that resulting from preferred fabric strain-softening at the margins as, for example, proposed by Hughes (1975) and observed on Jakobshavns Isbræ by Quintana and Echelmeyer (1986). Both processes will tend to localize the zones of high shear rate at the margins.

\section{REFREEZING OF MELTWATER IN FIRN}

Understanding the thermodynamics of the refreezing of meltwater in cold firn is fundamental to any discussion of the thermal regime of glaciers (e.g. Hooke and others, 1983) and for investigating the response of an ice sheet to climate change in terms of mass balance, shifts in the equilibrium line and the delayed outflow of increased melt (Pfeffer and others, 1990). Because of the large areal extent of the various melt-related facies, Jakobshavns Isbræ drainage basin provides a setting for studying phenomena related to this refreezing.

In particular, we were interested in (1) the meltrelated metamorphism of snow into firn and ice and the formation of the extensive ice layer formed at shallow $(\leq 0.4 \mathrm{~m})$ depths in the lower percolation and wetsnow facies, as was described in section 2 , and (2) in the transport of meltwater to greater depths by piping, such as has been discussed by Benson (1962), who observed the penetration of meltwater to depths in excess of $2 \mathrm{~m}$ in cold $\left(\sim-20^{\circ} \mathrm{C}\right)$ firn by the formation of vertical ice glands or "pipes". To this end, we installed a $3 \mathrm{~m}$ long thermocouple string at L30 (elevation $1520 \mathrm{~m}$ ) during the summer of 1986 . Temperatures at depths of 0.25 , $0.5,1.0,1.5,2.0,2.5$ and $3.0 \mathrm{~m}$ were recorded twice daily at local noon and midnight, from 19 June to 5 October, using a data logger. The sensor string was emplaced in a steam-drilled hole, which was back-filled with snow. There was some accumulation of snow in the later part of the summer, such that depths below the snow surface on 6 October were $0.25 \mathrm{~m}$ greater than those listed above.
On this date, an ice layer about $15 \mathrm{~cm}$ thick was present $0.68 \mathrm{~m}$ below the surface or $0.4 \mathrm{~m}$ below the "summer" surface. The temperature in the data-logger enclosure was also recorded (we term this the panel temperature). This enclosure was located at the surface on 19 June, but was partially buried under fresh snow in October. Its temperature could be significantly different from the actual air temperature because of radiational warming and insulation by the snow cover, but trends in temperature should be representative. Overall accuracy of the temperature measurements in the firn at this location was about $\pm 0.2 \mathrm{~K}$.

A shallow snow pit was dug at this site on 6 October 1986, and the density measured. Excluding the fresh snow on top, the mean density of the firn over the first meter was $450 \mathrm{~kg} \mathrm{~m}^{-3}$, and the overall mean density, including a $5 \mathrm{~cm}$ thick ice layer at $0.3 \mathrm{~m}$, was $530 \mathrm{~kg} \mathrm{~m}^{-3} .1$ year earlier, a $3 \mathrm{~m}$ pit was excavated at the same site. At that time the density was about $450 \mathrm{~kg} \mathrm{~m}^{-3}$ excluding ice layers. Inclusion of observed ice layers at depths of 0.30 , $0.75,1.05,1.3,1.8$ and $2.25 \mathrm{~m}$, which ranged in thickness from 50 to $150 \mathrm{~mm}$, leads to a mean column density of $490 \mathrm{~kg} \mathrm{~m}^{-3}$ for the upper $3 \mathrm{~m}$. We use an average firn density of $450 \mathrm{~kg} \mathrm{~m}^{-3}$ for the following calculations.
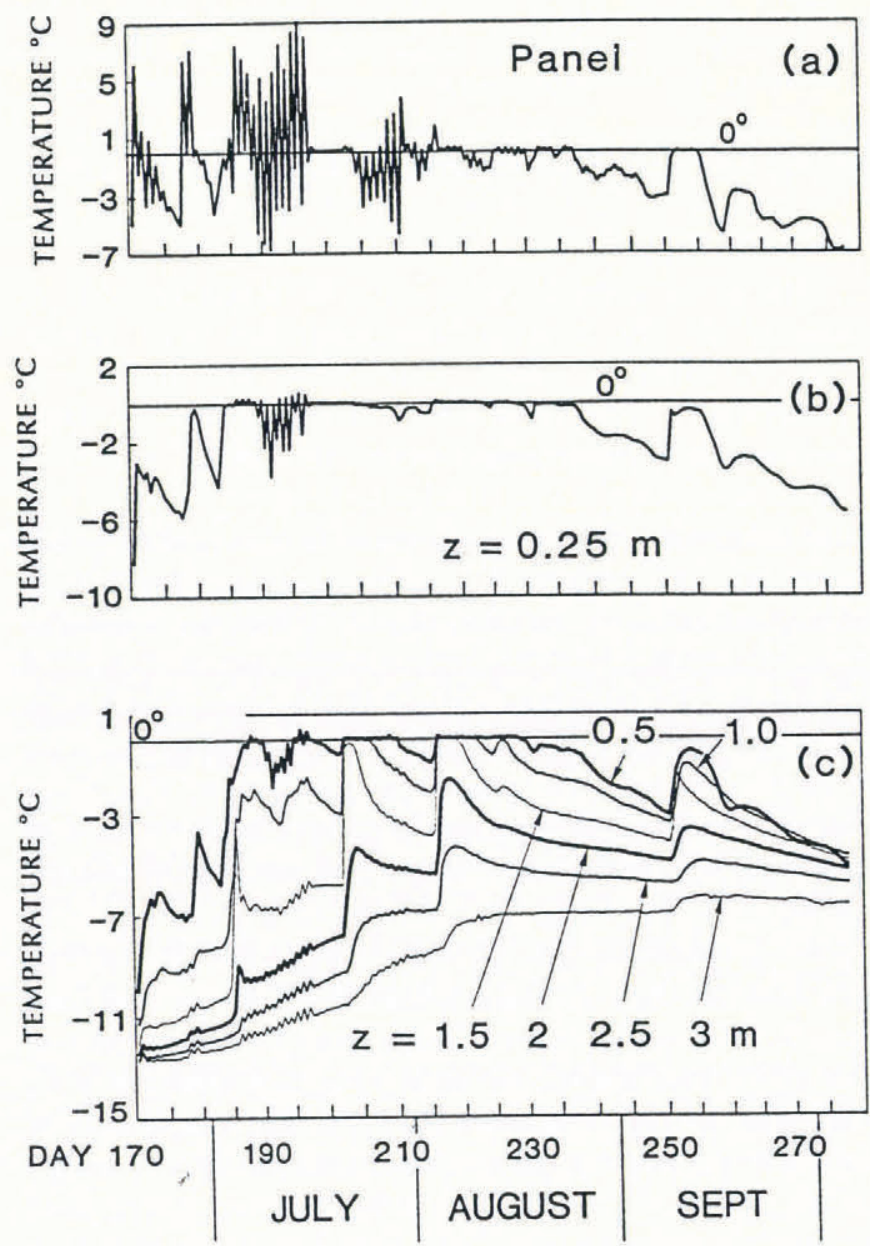

Fig. 7. Temperature measurements at shallow depths from 19 June to 7 October 1986. Location is L30 (1520ma.m.s.l.). (a) Panel temperature (inside enclosure at surface); (b) $0.25 \mathrm{~m}$ depth; (c) $0.5-3.0 \mathrm{~m}$ depth. Highfrequency structure in (a); (b) is diurnal temperature signal. 
The results of these temperature measurements are shown in Figure 7 . The panel temperature in the logger enclosure shows a diurnal variation during much of the summer. In early September, however, this diurnal signature dies off, probably because the sensor became buried by snow. Periods of thick fog eliminate the diurnal swings (e.g. day 197 to 203, or mid July). In late August, the mean air temperature begins to drop, and, except for a short period of surface melting (day 250 to 254), it undergoes a steady decline as winter approaches.

Air temperature provides forcing of the temperature in the near-surface layers, both directly by conduction and by meltwater production. Meltwater moves downward to some depth before refreezing, thereby transfering heat to greater depths over short time-scales. The effects of both processes are found in the data shown in Figure 7. Diurnal fluctuations occur at a depth of $0.25 \mathrm{~m}$ and, to a lesser extent, $0.5 \mathrm{~m}$, when the firn at these depths is below $0^{\circ} \mathrm{C}$. These fluctuations are due to conduction through the snow from the surface and the attenuation of radiational heating with depth. Below this depth, "diurnal" fluctuations also appear; they are probably caused by sensitivity of the logger. The large, step-like changes in temperature at all depths down to $3 \mathrm{~m}$ are due to refreezing of percolating water within the firn. These warming events occur periodically from midJune to early August and then once in early September. The firn at 0.25 and $0.5 \mathrm{~m}$ becomes isothermal at $0^{\circ} \mathrm{C}$ for about $1 \frac{1}{2}$ months, and the temperature at 1.0 and $1.5 \mathrm{~m}$ reaches $0^{\circ} \mathrm{C}$ for two short, isolated periods, but does not remain so at these latter depths, presumably because the firn away from the thermocouple string at those depths had not become saturated with melt. Below $1.5 \mathrm{~m}$ the firn is warmed substantially by refreezing, but the bulk temperature never reaches $0^{\circ} \mathrm{C}$.

Qualitatively, these measurements are useful for determining which particular facies L30 is located in, and for illustrating the difficulties in delineating facies boundaries from limited data. The annual snowpack at this site is about $0.8-0.9 \mathrm{~m}$ thick, and only the upper $0.5 \mathrm{~m}$ or so was raised to the melting point for any significant part of the summer. At a depth of $1.0 \mathrm{~m}$ the temperature did reach $0^{\circ} \mathrm{C}$ on occasion, but did not remain there, decaying rapidly to a lower value. This implies that the warming was only local in nature, and that the entire year's snow layer did not reach $0^{\circ} \mathrm{C}$, with heat flowing from the localized warming into the colder firn. Thus, by definition, L30 is in the percolation facies, and not in the wet-snow facies.

The temperature rise at all depths affected during the warming events usually occurred within $12-36 \mathrm{~h}$ of the increase in surface temperature. The timing of measurements precludes a resolution better than $12 \mathrm{~h}$. Within this resolution, there is no significant phase lag to the onset of warming. The peak warming does show an increasing lag with depth, however, amounting to about 3-4 d over $3 \mathrm{~m}$.

The magnitude of the temperature rise varies with depth and between events. During the rise beginning on day 201 (20 July), which we refer to as "event 201", an increase in temperature of $5.5 \mathrm{~K}$ was observed at $1.5 \mathrm{~m}$ depth. Above this depth the temperature rise was limited by the melting temperature, $0^{\circ} \mathrm{C}$. During event 215

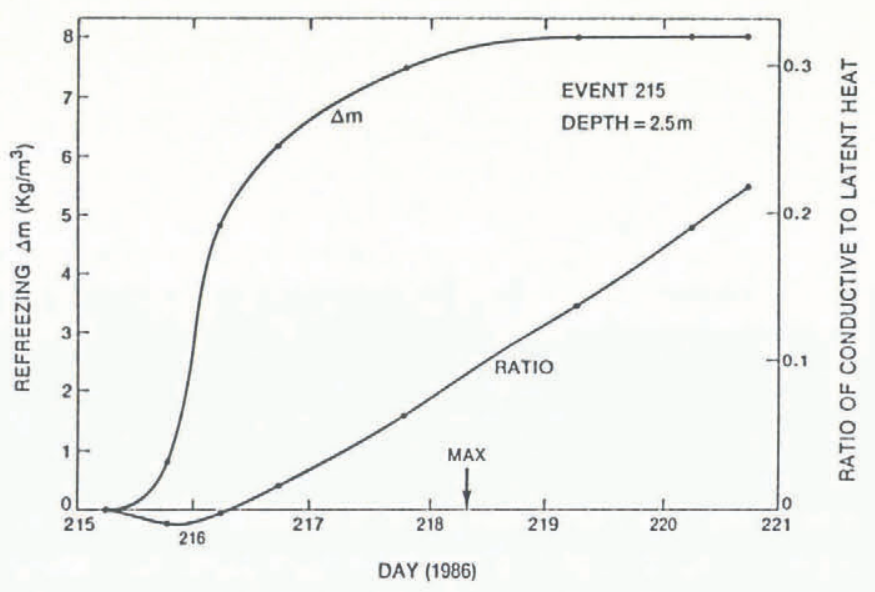

Fig. 8. Magnitude of observed temperature rise, $\Delta T$, at various depths during the melt events starting on days 201, 215 and 250.

the temperature became limited at $1.5 \mathrm{~m}$ as well. The variation in amplitude of the warming with depth for three events is shown in Figure 8. Events 201, 215 and 250 show similar trends with depth. The magnitude of the first two events is similar, while that for event 250 is less than half the others. During event 250 the temperature rise, $\Delta T$, leveled off to a nearly constant value at and above $1.5 \mathrm{~m}$, which is a different behavior than that observed during the other events. Also, as seen in Figure 7 , the temperature at $1.5 \mathrm{~m}$ does not follow the usual pattern of maintaining a plateau for several days. Instead it rises to a sharp peak and then decays nearly exponentially.

Extrapolation of the data shown in Figure 8 suggests that there is finite warming down to depths of $4 \mathrm{~m}$ at this location. As will be shown below, the warming at depth cannot be due to the conduction of latent heat released near the surface only (say, within the top $0.5 \mathrm{~m}$ ), because the time constant for diffusive heat propagation in firn is weeks at these depths. Instead, some meltwater must be infiltrating into the cold $\left(T \leq-6^{\circ} \mathrm{C}\right)$ snowpack to a depth of nearly $4 \mathrm{~m}$. The upper layers are not necessarily warmed to $0^{\circ} \mathrm{C}$ before melt reaches the deeper firn. A meltwater front can only travel a short distance in cold firn, this distance being on the order of $0.05-0.30 \mathrm{~m}$ (Colbeck, 1976; Pfeffer and others, 1990). "Fingering" along the front can only extend a few tenths of a meter beyond this percolation front (e.g. Marsh and Woo, 1984). Thus, it seems apparent that other mechanisms for meltwater migration in the vicinity of our measurement site are at play. Large-scale piping is a possibility. Similar mechanisms have been observed in even colder firn by Benson (1962).

The amount of meltwater that must refreeze at a given depth to cause the measured warming there can be estimated by the following analysis, in which the effects of conduction and latent-heat release are separated. Where the temperature remains below $0^{\circ} \mathrm{C}$ and variations in thermal conductivity can be neglected, the heat transport is described by

$$
\kappa \nabla^{2} T=\frac{\partial T}{\partial t}
$$


where $t$ is time, $\kappa$ is the thermal diffusivity and $\rho c$ is the volumetric heat capacity. This should be solved in three dimensions, applying a $0^{\circ} \mathrm{C}$ boundary condition at the surfaces of the pipes. However, because we have only one-dimensional information, it is assumed in this theory that the latent heat is released in a distributed fashion with a variability only in depth $z$, and that Equation (1) can be approximated by

$$
\kappa \frac{\partial^{2} T}{\partial z^{2}}+\frac{q}{\rho c} \simeq \frac{\partial T}{\partial t}
$$

where $q(z, t)$ is the power per unit volume due to the release of latent heat. These approximations are rather drastic, and the results should be interpreted accordingly.

The thermal properties of firn are not well known. The range of $\kappa$ for the mean density of $450 \mathrm{~kg} \mathrm{~m}^{-3}$ as obtained from the different formulae given by Paterson (1981, equations 10.1 and 10.2 ) is $4-9 \times 10^{-7} \mathrm{~m}^{2} \mathrm{~s}^{-1}$. Here we adopt a value of $7 \times 10^{-7} \mathrm{~m}^{2} \mathrm{~s}^{-1}$, as obtained from Hooke and others (1983). Furthermore, the density varies with time because of refreezing meltwater. However, the errors introduced by assuming constant density are much less than the above-quoted range in $\kappa$ from different empirical formulae.

Because we are mainly interested in the total latent heat released in an event, it is convenient to integrate Equation (2) over the duration $\Delta t$ of the event. The duration is assumed to be independent of depth. The result is:

$$
Q=\rho c\left(\Delta T-\kappa \frac{\partial^{2}}{\partial z^{2}} \int_{\Delta t} T(z, t) \mathrm{d} t\right)
$$

where

$$
Q(z)=\int_{\Delta t} q(z, t) \mathrm{d} t
$$

is the latent heat released per unit volume and $\Delta T$ is the observed temperature change in the interval $\Delta t$ since the event began. The mass $\Delta m$ of water refrozen per unit volume is given by

$$
\Delta m=Q / L
$$

where $L$ is the specific latent heat of freezing.

The second term on the righthand side of Equation (3) can be estimated by using a three-point approximation for the second derivative. The requirements are that at a depth of interest the temperature at adjacent depths be known, and that all three temperatures are less than $0^{\circ} \mathrm{C}$; the latter condition is necessary for the validity of Equation (2). This restricts the number of depths which can be analyzed with the data. The results are summarized in Table 1. The columns labeled "Ratio" in Table 1 show the ratio of the second term in Equation (3), which is the heat accumulated by conduction at a given depth, to $Q$, the latent heat released there. Although latent heat dominates, the conductive heat is seen to be significant in some cases.

The characteristics of the warming at a depth of $2.5 \mathrm{~m}$ during event 215 have been analyzed in some detail. The results are shown in Figure 9, which illustrates the time-
Table 1

\begin{tabular}{|c|c|c|c|c|c|}
\hline Depth & $\Delta m$ & Ratio & $\Delta m$ & Ratio & $\Delta m$ \\
\hline $\mathrm{m}$ & $\mathrm{kg} \mathrm{m}^{-3}$ & & $\mathrm{~kg} \mathrm{~m}^{-3}$ & & $\mathrm{~kg} \mathrm{~m}^{-}$ \\
\hline
\end{tabular}

Event 201

Event 215

Event 250

$\begin{array}{rrrrrrr}1.5 & - & - & - & - & 7.1 & 0.43 \\ 2.0 & 11.9 & 0.32 & - & - & 3.9 & 0.16 \\ 2.5 & 8.1 & 0.28 & 8.0 & 0.09 & 3.0 & 0.18\end{array}$

Total refreezing (snow thickness)

$0.05 \mathrm{~m}$

0.05

dependence of the amount of freezing and the ratio of conductive to latent heat as functions of time. The amount of refreezing, $\Delta m$, approaches its asymptotic value after roughly $3 \mathrm{~d}$. Then, at the time labeled by " $m a x "$ in Figure 9, the ratio of conductive to latent-heat release is about $9 \%$, and the maximum in temperature (shown in Figure 7) occurs. This would be a reasonable time to cut off the integration in Equation (3). If a longer $\Delta t$ is chosen, the asymptotic value of $\Delta m$ is unchanged, as it should be, but the importance of conduction, and therefore the errors involved in estimating it, increase. The negative ratio early in this event indicates a loss of heat by conduction at this depth.

Although we have sufficient data to evaluate the conductive term in Equation (3) only for the depths listed in Table 1, a rough estimate of $Q$, and therefore of the refreezing $\Delta m$, may be obtained at all depths by neglecting the conduction term. Equations (3) and (4) then give

$$
\Delta m \approx \frac{\rho c}{L} \Delta T
$$

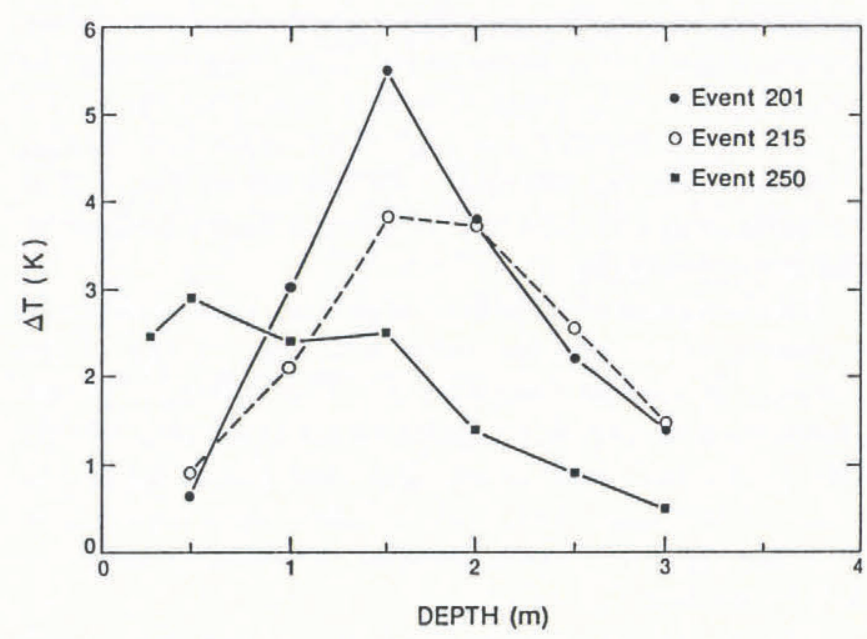

Fig. 9. The mass of meltwater per unit volume which refroze at a depth of $2.5 \mathrm{~m}$ during event 215 (3 August), and the ratio of the heat supplied by conduction to the heat supplied by refreezing as functions of time. 
The errors in this approach, where they can be evaluated, range from 9 to $43 \%$. Estimates of $\Delta T$ for each depth and each event are given in Figure 8. If these curves are integrated, and multiplied by $\rho c / L$, an approximation for the total mass of refrozen water per unit surface area is obtained for each event. In the last line of Table 1 this is expressed as a snow-equivalent thickness, using a density of $450 \mathrm{~kg} \mathrm{~m}^{-3}$. It is worth recalling that these results, although they seem reasonable, are rough because of the approximations which have been made.

These results, which are from the near-surface temperature measurements in the percolation/wet-snow facies during the melt season, are interesting in several respects. Small amounts of meltwater are apparently able to move through $3 \mathrm{~m}$ or more of firn that may be as cold as $-9^{\circ} \mathrm{C}$ and that has numerous $0.05-0.1 \mathrm{~m}$ thick ice layers in it. At this location, there was an ice layer at about $0.4 \mathrm{~m}$ in October, which may possibly have been equivalent to the extensive ice layer found throughout this region. However, not all meltwater stops at this shallow depth. Some finds its way to greater depths, and the refreezing of this melt thus leads to internal accumulation in at least the previous 3 years of firn, and to densification of the firn.

As noted earlier, it is generally believed that meltwater can "percolate" only about $0.05-0.1 \mathrm{~m}$ downward into cold firn (Colbeck, 1976) and about $0.2 \mathrm{~m}$ further by small-scale fingering (Marsh and Woo, 1984). (By "percolate" we mean bulk infiltration of liquid water into the permeable firn over a more or less continuous front.) Our results show that water can penetrate more than 30 times this far. Benson (1962, p. 20) found penetration depths of nearly $2 \mathrm{~m}$ for meltwater into cold firn (down to $-20^{\circ} \mathrm{C}$ ) as well. Benson showed direct evidence for "piping" of liquid down to these depths, with subsequent freezing into ice glands and lenses, and accompanying warming of up to $10 \mathrm{~K}$. Although we have no such direct evidence, we believe that meltwater at L30 was also able to penetrate by piping to $3 \mathrm{~m}$ depth.

These results indicate that piping is a dominant mechanism for heat transfer in firn where there is surface melting, and that piping can transfer meltwater and, therefore, heat, past "impermeable" ice layers at depth. As such, it is important in determining the meltwater storage capacity of the firn and its impact on meltwater outflow (and, hence, sea-level change) during prolonged periods of warming. The formation of the extensive ice layer at a depth of $0.4 \mathrm{~m}$ in this region is probably related to the mean depth of piping and/or percolation. However, there also must be localized extremes such as that observed at L30.

The discussion above is predicated on the condition that our observational set-up did not influence the meltwater distribution. That the sensor string was emplaced in a hole which was drilled using steam and necessitated wires coming down from the surface may have, in fact, provided a nucleus for a meltwater "pipe". Liquid may have been preferentially transported along the exisitng structure. However, one must note that a $2 \mathrm{~m}$ long pipe and lens structure observed by Benson (1962) in much colder snow was not formed under disturbed conditions. In any case, this discussion points to the need for continued observational and experimental investigation of the processes of piping, using proper care in the observational techniques. In addition, a more realistic model of heat flow from a three-dimensional pipe should be utilized.

\section{CONCLUSIONS}

Ablation within the Jakobshavns Isbræ drainage basin accounts for about $6 \%$ of the estimated total meltwater flux of the Greenland ice sheet, which is about the same as the proportion of the total ice-sheet area occupied by this drainage basin. This implies that this basin provides a representative sample of the mass balance of the ice sheet as a whole. The ratio of the calving flux (Part III) to ablation flux (both surface and basal melting), designated "CAR", is about 2. Many tide-water/calving glaciers have much larger values of CAR, and the relatively low value found for Jakobshavns Isbræ indicates the relative importance of its large ablation area in determining the outflow of mass from this glacier/ice-stream system. Basal melting beneath this fast-moving glacier provides a substantial fraction of its total melt, roughly $20 \%$.

The equilibrium line occurred at an elevation of $1210 \mathrm{~m}$ during the period of study (1984-86). Comparison with measurements taken along a line about $60 \mathrm{~km}$ to the north (Ambach, 1977; Thomsen, 1984) shows that the ELA varied over a range of $200-300 \mathrm{~m}$ during a period of about 40 years. This variation is related to interannual meteorological variations, and is clearly not easily interpreted in terms of a changing climate.

Accumulation is lower than expected by extrapolation from the results of Benson (1962) about $100 \mathrm{~km}$ to the north. This may indicate the presence of a precipitation low in this region of the ice sheet, as predicted by Bender (1984). The existence of such a zone of low accumulation would significantly affect any regional mass-balance estimate for Jakobshavns Isbræ drainage basin. Comparison of the measured calving flux (Part III) and the estimated balance flux at the terminus shows that either the ice sheet in this region is nearly in balance, if a precipitation low is assumed, or it must be thickening at a rate of about $100 \mathrm{~mm}$ year $^{-1}$ if the accumulation is extrapolated from the results found along the EGIG line. Further data must be acquired within the drainage basin to answer this question.

Turning now to the temperature measurements, we have seen that the $12 \mathrm{~m}$ temperature exhibits an altitudinal gradient whose magnitude is somewhat less than both that predicted by Ohmura (1987) based on climatological data only and that found by Benson (1962) at higher elevations. However, the difference in gradients is not large. This is interesting in that the combined effects of: (1) ablation in removing the winter's cold layer, (2) latent-heat release by refreezing in the firn, (3) buffering of the warm summer air temperatures by the melting point, and (4) the cooling associated with intense crevassing along the ice stream, could be expected to substantially alter the signature of the climatological lapse rate in the near-surface ice. The magnitude of warming in the wet-snow facies is not as large as might be expected from other studies on polar and sub-polar glaciers 
(e.g. Paterson, 1981). This may be due to a thin winter snowpack.

There is strong variation in temperature across the ice stream which may be related to deformational (shear) heating along the margins. Higher temperatures near the margins will help localize the ice stream through positive feed-back of the reduced ice viscosity, and, as such, will play an important role in the stability of an ice stream within an ice sheet.

Refreezing of meltwater produces warming down to substantial depths in cold firn. This is shown by measurements within the upper wet-snow/lower percolation facies, where piping of meltwater affected temperatures down to a depth of 3-4 m. Piping and refreezing of surface meltwater provide the source for internal accumulation within previous years' firn layers. Of course, not all meltwater is "piped" to these depths, as is shown by the presence of a pervasive ice layer at a depth of 0.3 $0.4 \mathrm{~m}$ in the wet-snow and lower percolation facies. The relationship between meltwater transport to depth via piping and infiltration to shallow depths needs further investigation before the effects of increased surface melting on sea level can be addressed.

\section{ACKNOWLEDGEMENTS}

The results reported here could not have been obtained without the field help of T. Gaecke, G. Liston, M. Lockwood and C. Petersen. S. Watson and K. Swanson from PICO helped with logistical support. Brigette, J. Lindmark and K. Nordin provided excellent helicopter support during less than ideal conditions in fall and winter. C. Gering deciphered the original manuscript and prepared the final copy.

Several comments by R. Hooke and an anonymous reviewer helped to improve the original manuscript.

This work was supported by U.S. National Science Foundation under contract number DPP-84-06818.

\section{REFERENCES}

Ambach, W. 1963. Untersuchungen zum Energieumsatz in der Ablationszone des grönländischen Inlandeises (Camp IV-EGIG, $69^{\circ} 40^{\prime} 05^{\prime \prime} \mathrm{N}, 49^{\circ} 37^{\prime} 58^{\prime \prime} \mathrm{W}$ ). Medd. Grønl., 174(4).

Ambach, W. 1977. Untersuchungen zum Energieumsatz in der Ablationszone des grönländischen Inlandeises Nachtrag. Medd. Grønl., 187(5).

Bader, H. 1961. The Greenland ice sheet. CRREL Monogr. I-B2.

Bauer, A., W. Ambach and O. Schimpp. 1968. Movement et variation d'altitude de la zone d'ablation oest (latitude moyenne $60^{\circ} 40^{\prime} \mathrm{N}$ ) de l'inlandsis du Groenland entre 1948 et 1959. Medd. Grønl., 174(1).

Bender, G. 1984. The distribution of snow accumulation on the Greenland ice sheet. (M.S. thesis, University of Alaska Fairbanks.)

Benson, C. S. 1962. Stratigraphic studies in the snow and firn of the Greenland ice sheet. SIPRE Res. Rep. 70.

Bindschadler, R. A. 1984. Jakobshavns glacier drainage basin: a balance assessment. J. Geophys. Res., 89(C2), 2066-2072.

Bindschadler, R. A., H. J. Zwally, J. Major and A. Bren- ner. 1989. Surface topography of the Greenland ice sheet from satellite radar altimetry. Washington, DC, National Aeronautics and Space Administration. (NASA SP-503.)

Braithwaite, R. J. and O. B. Olesen. 1990. Simple energybalance model to calculate ice ablation at the margin of the Greenland ice sheet. J. Glaciol., 36(123), 222228 .

Braithwaite, R.J. and H.H. Thomsen. 1984. Runoff conditions at Kuussuup Tasia, Christianshåb, estimated by modelling. Grønl. Geol. Undersøgelse. Gletscher-Hydrol. Medd., 84(2).

Colbeck, S.C. 1976. An analysis of water flow in dry snow. Water Resour. Res., 12(3), 523-527.

Echelmeyer, K. and W. D. Harrison. 1990. Jakobshavns Isbræ, West Greenland: seasonal variations in velocity — or lack thereof. J. Glaciol., 36(122), 82-88.

Echelmeyer, K., T.S. Clarke and W.D. Harrison. 1991. Surficial glaciology of Jakobshavns Isbræ, West Greenland: Part I. Surface morphology. J. Glaciol., 37(127), 368-382.

Hooke, R. LeB. 1976. Near-surface temperatures in the superimposed ice zone and lower part of the soaked zone of polar ice sheets. J. Glaciol., 16(74), 302-304.

Hooke, R. LeB., J.E. Gould and J. Brzozowski. 1983. Near-surface temperatures near and below the equilibrium line on polar and subpolar glaciers. $Z$. Gletscherkd. Glazialgeol., 19(1), 1-25.

Heuberger, J.C. 1954. Groenland glaciologie. Vol. I. Forages sur l'inlandsis. Paris, Hermann and Cie.

Hughes, T. 1975. The West Antarctic ice sheet: instability, disintegration, and initiation of ice ages. Rev. Geophys. Space Phys., 13(4), 502-526.

Iken, A., K. Echelmeyer, W. Harrison and M. Funk. In press. Temperature and water level measurements in deep boreholes in Jakobshavns Isbræ, Greenland. J. Glaciol.

Marsh, P. and M.-k. Woo. 1984. Wetting front advance and freezing of meltwater within a snowcover. 1. Observations in the Canadian Arctic. Water Resour. Res., 20(12), 1853-1864.

Müller, F. 1976. On the thermal regime of a high-Arctic valley glacier. J. Glaciol., 16(74), 119-133.

National Research Council. 1985. Glaciers, Ice Sheets, and Sea Level: Effect of a $\mathrm{CO}_{2}$-induced Climatic Change. Report of a workshop held in Seattle, Washington, September 13-15, 1984. Washington, DC, United States Department of Energy.

Ohmura, A. 1987. New temperature distribution maps for Greenland. Z. Gletscherkd. Glazialgeol., 23(1), 1-45.

Paterson, W.S. B. 1981. The physics of glaciers. Second edition. Oxford, etc., Pergamon Press.

Pelto, M. S., T. J. Hughes and H. H. Brecher. 1989. Equilibrium state of Jakobshavns Isbræ, West Greenland. Ann. Glaciol., 12, 127-131.

Pfeffer, W. T., T. H. Illangasekare and M. F. Meier. 1990. Analysis and modeling of melt-water refreezing in dry snow. J. Glaciol., 36(123), 238-246.

Quintana, C. and K. Echelmeyer. 1986. Ice fabric analysis from Jakobshavns glacier, Greenland. In Chap- 
man Conference of Rapid Glacier Flow, Whistler, B.C., May 1986. Abstract volume. Washington, DC, American Geophysical Union, 16.

Radok, U., R. G. Barry, D. Jenssen, R. A. Keen, G. N. Kiladis and B. McInnes. 1982. Climatic and physical characteristics of the Greenland ice sheet. Parts I and II. Boulder, $\mathrm{CO}$, University of Colorado. Cooperative Institute for Research in Environmental Sciences.

Reeh, N. 1985. Greenland ice-sheet mass balance and sealevel change. In National Research Council. 1985. Glaciers, Ice Sheets, and Sea Level: Effect of a $\mathrm{CO}_{2}$-induced Climatic Change. Report of a workshop held in Seattle, Washington, September 1315, 1984. Washington, DC, United States Department of Energy, 155-171.

Thomsen, H.H. 1984. Mass balance measurements at the margin of the inland ice near Jakobshavn, West Greenland. Polarforschung, 54(1), 37-41.

Williams, R. S., Jr, D. K. Hall and C.S. Benson. 1991. Analysis of glacier facies using satellite techniques. $J$. Glaciol., 37(125), 120-128.

Zwally, H.J. 1989. Growth of Greenland ice sheet: an interpretation. Science, 246(4937), 1589-1591.

Zwally, H. J., A. Brenner, J. Major, R. Bindschadler and J. Marsh. 1989. Growth of Greenland ice sheet: measurement. Science, 246(4937), 1587-1589.

The accuracy of references in the text and in this list is the responsbility of the authors, to whom queries should be addressed.

\section{APPENDIX}

\section{THE DEPTH OF SEASONAL TEMPER- ATURE VARIATION}

The effect of ablation on the depth at which the seasonal temperature variation is reduced to $1 / \mathrm{e}$ of its surface amplitude is illustrated by the following model. The temperature $T$ is described by

$$
\kappa \frac{\partial^{2} T}{\partial z^{2}}+a \frac{\partial T}{\partial z}=\frac{\partial T}{\partial t}
$$

where $z$ is depth, $t$ is time, $\kappa$ is the thermal diffusivity and $a$ is the ablation rate in ice-equivalent units. $a$ is taken to be equal to the upward velocity of the ice. For simplicity, it is assumed that $a$ is constant throughout the year. The solution for a time-harmonic surfacetemperature condition has the form

$$
T \propto \operatorname{Re}\left\{\mathrm{e}^{i \omega t+c z}\right\}
$$

where $\omega$ is the angular frequency corresponding to a period of 1 year, and the complex argument $c$ satisfies

$$
\kappa c^{2}+a c-i \omega=0 .
$$

Solving Equation (A3) for the real part of $c$, subject to the constraint that the solution, Equation (A2), dies off at large depth, yields

$$
\operatorname{Re}\{c\}=\left(\frac{\omega}{2 \kappa}\right)^{\frac{1}{2}}\left[1+\frac{a}{(2 \omega \kappa)^{\frac{1}{2}}}+\frac{a^{2}}{8 \omega \kappa}+\ldots\right] .
$$

The characteristic penetration depth (i.e. the exponential decay factor) for seasonal temperature variations, $z_{0}$, is given by $-1 /[\operatorname{Re}\{c\}]$, or

$$
z_{0} \approx\left(\frac{2 \kappa}{\omega}\right)^{\frac{1}{2}}\left[1-\frac{a}{(2 \omega \kappa)^{\frac{1}{2}}}+\frac{3}{8} \frac{a^{2}}{\omega \kappa}\right]
$$

where $T \propto \mathrm{e}^{-z / z_{0}}$. The quantity $(2 \kappa / \omega)^{\frac{1}{2}}$ is the characteristic depth when the vertical velocity, or ablation rate, is zero (see, for example, Paterson, 1981). The correction terms reduce this depth by about $5 \%$ when $a=1 \mathrm{~m} \mathrm{a}^{-1}$ and by $16 \%$ when $a=4 \mathrm{ma}^{-1}$. There will also be a phase shift of the temperature response at depth associated with the imaginary part of $c$. 